\title{
EDITORIAL
}

\section{Tri-national Workshop, Warsaw, November 2006 - Introductory Remarks}

As a follow-up of two preceding series of international meetings entitled "Science and Art in Europe", a third, tri-national workshop with participants from Poland, Germany and the Czech Republic was held in Warsaw on 16-17 November 2006. The first two series of scientific and cultural events, organized by the Max Planck Society and their respective partners, had taken place in November 2002 in Warsaw, Krakow and Poznan in the form of several bilateral Polish-German symposia, and in May 2005 in Berlin, Dresden and Jena, this time with scientists from Germany and all new central and eastern EU member states. The overwhelming success, including the formation of several fruitful bi- or multilateral partnerships, called for the continuation of this new type of pacemaker for the eastward extension of the already existing, dense scientific network throughout western Europe.

Like the two preceding events, and as deliberately planned with the initial concept, this third one, organized by Marta Miaczynska and colleagues at the International Institute of Molecular and Cell Biology in Warsaw, was yet another variation of the basic theme: a single, two-day symposium in a fairly broad area of cell and molecular biology, with the majority of Czech,
Polish and German speakers being carefully selected young scientists at the Ph.D. student and postdoctoral levels. Again, the success was overwhelming. Whether young or very young in their scientific career, all speakers presented, mostly in fluent English, exciting new data in well-organized and well-illustrated talks. The spontaneous results were lively discussions after the presentations, as well as during breaks and meals, and the formation of several new partnerships.

At the end, a strong interest in the further continuation of this newly established tradition was unanimously expressed. There was equally unanimous agreement that, after this and the preceding meetings in Poland and Germany, Prague would be a suitable place for the next one and should be followed by others. Most importantly, all participants were convinced that there was no better way than personal meetings and collaborations among young people with common interests and open minds to pave the way for a prosperous, truly integrated Europe.

Klaus Hahlbrock Max Planck Institut für Züchtungsforschung, Carl-von-Linné-Weg 10, D-50829 Köln, Germany E-mail address: hahlbroc@mpiz-koeln.mpg.de 